\title{
The Important Tendencies in the Development of Creative and Creative Potentials in Youth
}

\author{
SAMIYEVA Shaxnoz Xikmatovna, HERNIAVSKYI Volodymyr Georgievich, ASADOVA \\ SitoraSa' dullayevna, ASLANOVA Nozima Hakimovna, MIRSHAYEV Ulugbek Muzafarovich
}

\begin{abstract}
This article discusses the role of creativity, creative thinking-creativity in the development of the worldview of young people, analyzes the issues of their involvement in creative and vocational training.It provides information on design, which is an integral part of applied art. Also, these concepts determined the role of an aesthetic worldview in the development of the creative abilities of youth.
\end{abstract}

Index Terms: worldview, creativity, education, talent, creative thinking, creativity, intellectual abilities.

\section{INTRODUCTION}

Mature qualities such as spiritual and moral purification, intellectual and scientific development, professional skills and creative abilities that are essential to the development of society and personality are not emerging spontaneously. The basis of all lies in the education of the younger generation in the family, in the educational institutions.

Upbringing young people mentally and physically, mentally and spiritually is one of the most important and urgent issues oftoday. One of the principles of continuous education, the priority of education is the priority of its development, the authority of knowledge, education and high intelligence. The state policy in the field of personnel training envisages the formation of a fully developed individual - a citizen through a system of continuous education, which is inextricably linked with the intellectual and spiritual and moral education of the person.

\section{REVIEW OF LITERATURE}

Upbringing a young generation with a mature, harmonious and high intellectual level has always been a very important and important task. At the same time, this task is large and complex. The mentality of youth is complex, but the factors that influence it and its effects are very diverse. Therefore, the study of pedagogical and psychological tools for the study and development of young people's creative abilities is an urgent problem today. Creative activity is an important aspect of a person's creative ability, and it involves the creation of new items that are not previously available (2000). The creative abilities and the result reflect the unique, original, and the socio-historical nature of the activity. The qualities of a person's creativity develop only when certain conditions are present. For example, freedom of criticism, creative

Revised Manuscript Received on December 22, 2019

SAMIYEVA Shaxnoz Xikmatovna, Bukhara engineering and technology institute, Uzbekistan

HERNIAVSKYI Volodymyr Georgievich, National Academy of Fine Arts and Architecture, Ukraine.

ASADOVA SitoraSa' dullayevna, Bukhara engineering and technology institute, Uzbekistan

ASLANOVA Nozima Hakimovna, Bukhara region in service and retraining institute of public educators, Uzbekistan

MIRSHAYEV Ulugbek Muzafarovich, Bukhara state university, Uzbekistan discussion, exchange of ideas and the struggle between them contribute to creative development. Psychological and philosophical researches have shown that the creative activity of the individual is carried out in several stages. For example, in 1924 the English scientist G. Wallace (1926) noted that this process consists of four stages:
1) preparation;
2) the emergence of ideas;
3) their full reflection;
4) verification (control).

The emergence of ideas and their reflection does not mean that the creative process has conscious-will control. On the contrary, activities are often carried out involuntarily, by chance. Regarding to this many researchers doubt that this process will be productive. However, researches conducted over the next year have shown that randomness fills up with voluntary and conscious activities.

The creative person does not control himself in the process of creation, even though he observes the general state of thought (imagination, discovery, unexpected decisions, etc.). F. Galton put forward the idea that an individual can organize activities only if they have special abilities and studied the psychological qualities of a creative person. However, F. Galton (2001) andCh. Lombrozo'sviews which investigates ingenuity and its specific aspects have been sharply criticized. Since the 20s of the last century, the interest and approach to the study of personality, talent and potential has changed dramatically through advances in science and technology. Because, before that, special tests could not assess human mental abilities and assess the level of creativity in situations where specificity and unusual thinking were observed.

"Creative activity," saysM. Matyushkin (1965)is a system related to cognitive processes". A number of psychologists N.P. Shcherba(1987), W. S. Yurkevich(2011), E. L. Yakovleva (2015)consider that: "Creative activity is the process of human activity. The personality of the student is formed in the course of various activities".

American psychologist E.Fromm (2002) comments on the concept of "creativity" as follows: "Creativity is a fascination and understanding of the ability to make decisions in a variety of unusual situations. The ability to create news and gain a deeper understanding of personal experiences."

Research shows that creative abilities (its growth and decline) require many organizational conditions.For example, when a person's activities are not criticized and underestimated, and they do not feel any fear, young people are

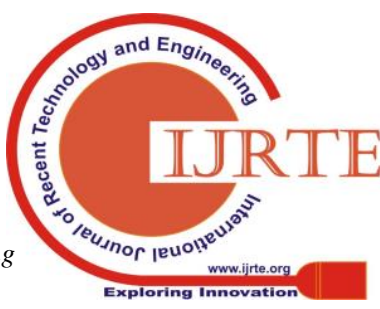


more effective at performing creative and intellectual tasks.In the rapidly developing environment of technology and technology, the quest for new knowledge fields has intensified.In particular, in the field of culture, light industry, design and consumer services, special attention is paid to the creative nature of this activity and the use of technical and technological assistance.To do this, a specific, non-standard way of thinking is also important.

\section{METHODOLOGY}

Abilities are defined as psychic qualities that help a person acquire knowledge, skills and abilities more easily and successfully engage in any activity. The abilities only show up in activities. During the perception, for example, subtle differences in color, clearness of objects, understanding of proportional proportions (in the work of artists), absolute listening (with music), observation (in many activities), and etc. Thinking process of an individual(understanding and solving the problem, the depth of his thinking, critical thinking, thinking) is clearly reflected in his abilities. The ability arises and develops in the course of action. Moreover, the basic meaning of talent is the concept of "ability" (1985). The ability will depend on the process of acquiring knowledge, skills and skills of young people. The role of their congenital abilities and talents is important in the intellectual development of young people. Young people with congenital abilities can quickly and successfully obtain every educational and vocational education of adults and implement them. But not all the young people can obtain that talent as a congenital ability.

Art in broad means encircles art works, likewise, its process of creating and using. Art is being developed connecting with social improvement.

The power of art works, especially, in the field of design, in its nativity and perceptivity, it can influence on people's inner-spiritual world and emotion. Because of this young modeler - designers art should be considered. In the process of creating modern clothes widely using rich cultural heritage, increasing its effect and productivity can be significant factor.

When young artists working in the field of design, the difficult, contrary, magnetic, full of passion life spectacle embodies in front of him. As they try to expressthis spectacles on their drafts, clothes, they remain as child of their epoch, their nation, their conviction. In this clothes especially, general humanitarian and national customs togetherness is brightly appears.

Beauty, sparkling of colors, the identity of patterns to the location, brilliance of our national clothes, always interested expert designers. Beauty and comfort, esthetic measures are leading persuasion of literary project. It would be great if this beauty expressed our nationality in itself, consequently, as our first President I.A.Karimov said, "We must intensify factors that form peoples mind basing on historical native customs, tradition andceremonies".

The task of young designers is to create clothes which are suitable to continental climate, similar to the mentality, traditional customs and expressing national identity. It would be great to learn the cloth and natural material making experiences of our predecessors(1990). Nowadays interest to our national clothes and requirement is growing day by day all over the world. Embroidery, patterns on clothes, skillfully used materials such as adras, banoras, bekasam attracts foreign tourists. According to these requirements young modeler - designers creating their modern clothes usingnational traditions of nation in their cloth collections.

Nowadays, it is important task to create new methods of perfecting the possibilities, considering how rich is artistic capability of our young generation, their creative skills and esthetic outlook.

Especially, we must develop youngster's education, creating, intellectual and esthetic outlook, coordinate intellectual capabilities to the modern requirements, opening new ways of possibilities, bring up young specialists as a mentally mature, morally strong andliterary quick - witted when they are living with the sense of competing with other young people from the other part of the world. Therefore, we must achieve to the perfection in the field of artistic design, and develop esthetic outlook, creative activity of young generation as well as our great predecessors.

The main task of the teachers of higher educational institutions to show students the abilities, talents and creative thinking - to show creativity in areas that are comfortable and interesting to them. Especially when an unusual, innovative (non-standard) work in design is observed one may think that only proficient or very talented person can do it. Whereas, only a person of high taste and ability can create works of art that amaze people. Despite the fact how aptitude, talented, and creative the students are, they are not perfect in extracurricular activities. One of the most effective ways to develop creativity and creativity is to involve design students in productive creativity and vocational training, to organize classes creatively, and to use a variety of non-traditional teaching methods.

Learners use creative thinking, creativity, creative abilities and talents in a variety of ways in the learning process to develop a wide range of thinking, willpower, self-confidence, activity and work habits, ability to work towards goals. should be filled. Then, the goals of upbringing and educationcan be fully achieved (2002). To achieve these goals, students must continuously work on themselves, think independently, and actively participate in social relations, and demonstrate their creative abilities and talents, actively using their inner natural abilities. In summary, we do not see talent as a natural feature of human beings, but we often see that young people have a natural disposition, that is, talent, based on their ability to develop. In many cases, we understand the natural ability that lies in the development of talent. In our opinion, there are several ways for students to improve their creativity:

1. Applied and Fine Arts. As a result of this activity students develop the process of fantasy and imagination. This development, in turn, offers new horizons for thinking. As a result, the coordination of these two cognitive processes creates the discovery of creative abilities.

2. Music. The sense of sight plays a leading role in people. Ninety percent of the information is received by visual ability. However, music cannot be seen. It is heard and 
felt. We can therefore assume that engaging in music activates the "drowse" features of the youth psyche.

3. Reading. Reading is a powerful tool for developing creativity in young people. Because young people imagine the process of events, they "live" in the world of heroes of the work, rejoice and care. This process helps them to develop their imagination.

4. Design and independent research. This activity promotes the emergence of the natural ability of young people and the manifestation of creative abilities in the initial processes.

Ensuring successful participation of the youth in these activities will help young people to find their own way of life and achieve successful results in their professional activities. Based on this conclusion, we have developed the following recommendations for developing young people's creative abilities:

- naturally, young people do not have the knowledge, skills and abilities required to achieve their goals. They must constantly pursue themselves for the ultimate goal, actively participate in the process of social relations, develop their creative abilities;

- It is a mistake to say that students who have not mastered subjects during the course are mistaken, the first task of a teacher is to study the young psychological character of each student, to identify his interests and wishes, and to develop pedagogical measures;

- active daily activities are required to develop students' creative abilities. With the help of the activity, students form a relationship with the environment, thereby developing their creative abilities, improving their character traits and development;

It is advisable for students to develop their creative abilities, to work with them individually, to improve their extracurricular activities, to develop independent thinking and to plan their leisure time effectively.

\section{RESULTS}

Coming from that mentioned above followings may be done:

Increasing attractiveness, effectiveness, confidence through developing esthetic outlook of young people;

Learning deeply and carefully relation of art with esthetics, morality and other subjects;

Creating opportunity for increasing value of esthetic outlook and intellect in the improvement of art;

Further developing field of design and more demonstrating it all over the world;

Popularize art of practical decoration, national clothes and therefore paying attention to improve handicraft;

Producing mature and experienced personnel for developing types of art and design;
Teaching youngsters secrets of art and educating, upbringing to improve their outlook;

Giving necessary advices to future experts about connection between art and design in the process of education.

It very important, bring to perfection young people, develop their outlook, arose love for their country in their heart for improving their esthetic outlook and bringing up in these terms. Therefore, we must always struggle and worry aboutmature spiritual world, esthetic outlook, moral maturity of our children.

Analyzing the factors of the development of creativity skills in students, we focused on the extent to which students perceive the importance of professional activity. On this basis, we managed to determine the following:

- existence of interest in the subject of study;

- the desire to master a particular subject;

- the advantage of striving to devote oneself to students, education

- self-realization of pedagogical ability;

- the desire for higher education;

- a tendency to pedagogical creativity.

Problematic education in the development of students' creative abilities in contrast to other types of education includes a system of knowledge, skills and qualifications in learners, along with the formation of high intelligence activity, self-development.At the same time, special attention should be paid to the application of creative environment, a certain spiritual and psychological state, organizational, methodical, psychological measures among students.In this process, it is desirable to provide scientifically based information about the pedagogical innovations existing in students, their characteristic features, application parameters, innovative teaching opportunities.

\section{CONCLUSION}

On the basis of the above, we can conclude that such specialists can approach both students and themselves creatively as a subject of the pedagogical process.

An important pedagogical condition for the development of creative abilities in students is its acquisition of independent knowledge and orientation to creative thinking. The problems mentioned above will be the basis for changing the target direction.

\section{REFERENCES}

1. Wallas, G. (1926). The art of thinking. London: Jonathan Cape Ltd Galton, F.(2001).Inquiries into human faculty and its development.

3. Matyushkin, A.M. (1965). Psychology of Thinking: Per. with him. and English. / Ed. and with entry.

4. Scherbo, N.P. (1987). Mutual evaluations of partners as a personal factor of dialogical thinking: a dissertation ... of a candidate of psychological sciences. Moscow. 221 p.

5. Yurkevich,W.S. (2011). Organization of psychological support for gifted adolescents in the process of their professional self-determination. Guidelines. Moscow.

6. Yakovleva, E.L.(2015).Penetrating the worlds of inclusion. Kazan. 223 p.

7. Fromm, E. (2002). Humanist psychoanalysis. Compiled by the general editorship of V.B. Leibin: Peter.-544 p.

8. Al-Farabi. (1985).Historical and philosophical tracts.Alma-ata. $18 \mathrm{p}$. 
9. Davletshin, G.M.(1990). Psychological bases of education. Tashkent.

10. Karimova,V.M.(2002).Psycology. Tutorial book.T.: Publishing house of national heritage named after A. Kadiri.205p.

11. Karimova,V.M.(2000).Sunnatova R. Methodical instructions on independent thinkingfor organizing lessons. Tashkent. 